\title{
Vertical flux of phytoplankton and particulate biogenic matter in the marginal ice zone of the Barents Sea in May 1993
}

\author{
Inger J. Andreassen*, Paul Wassmann \\ Norwegian College of Fishery Science, University of Tromse, N-9037 Tromsø, Norway
}

\begin{abstract}
Hydrography, nutrients, chlorophyll a (chl a), phaeopigments (phaeo) and phytoplankton abundance as well as the vertical flux of particulate organic carbon and nitrogen (POC and PON) and pigments in the upper $200 \mathrm{~m}$ were investigated at 4 stations along a north-south transect in the Barents Sea in May 1993. Two stations were located in Arctic water and 2 in Atlantic water. The northernmost station had a well-developed ice edge bloom with high abundance of Fragilariopsis sp., Thalassiosira spp. and Chaetoceros spp. The phytoplankton community at the ice edge and the northernmost Atlantic station was dominated by Phaeocystis sp. colonies in concert with Chaetoceros spp. and Thalassiosira spp. The phytoplankton community at the southernmost station was dominated by large Chaetoceros spp. cells. Vertical flux of biogenic matter in the upper water column $(20-100 \mathrm{~m})$ varied along the transect (2.1-13.3 $\mathrm{mg} \mathrm{chl} \mathrm{a} \mathrm{m} \mathrm{m}^{-2} \mathrm{~d}^{-1}, 0.6-11 \mathrm{mg}$ phaeo $\mathrm{m}^{-2} \mathrm{~d}^{-1}$ and $\left.409-1090 \mathrm{mg} \mathrm{POC} \mathrm{m} \mathrm{d}^{-1}\right)$,

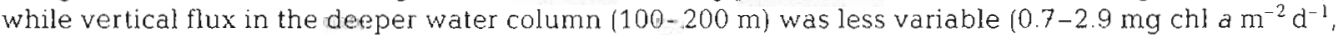
1.5-6.5 $\mathrm{mg}$ phaeo $\mathrm{m}^{-2} \mathrm{~d}^{-1}$ and 200-300 $\mathrm{mg}$ POC $\mathrm{m}^{-2} \mathrm{~d}^{-1}$ ). Hydrographic conditions, nutrient status and species specific sinking rates did not have a profound influence on the vertical flux of phytoplankton. High daily loss rates of $\mathrm{chl} a$ ( 4 to $18 \% \mathrm{~d}^{-1}$ of standing stock chl a) and microplankton at 2 stations (southernmost and northernmost Atlantic) was probably caused by high production of extracellular carbon, increasing the aggregation potential of the phytoplankton community. Evidence of incomplete dissolution of Phaeocystis sp. colonies was observed to a depth of $200 \mathrm{~m}$. Faecal matter and detritus were the main vehicles for the vertical export of organic matter to deeper water (below $100 \mathrm{~m}$ ). Protozoan grazing was more important in retaining organic matter and nutrients in the upper water than mesozooplankton grazing.
\end{abstract}

KEY WORDS: Vertical flux $\cdot$ Phytoplankton S Spring bloom - Barents Sea

\section{INTRODUCTION}

Spatial and temporal patterns in the vertical flux of biogenic matter are central to the understanding of elemental dynamics and food-webs in the ocean (Smetacek et al. 1984, Legendre 1990, Wassmann 1991a). The dynamics of vertical flux of biogenic matter, and to a lesser extent the composition of exported matter, was investigated in the Barents Sea during the period 1984-1989 (Wassmann 1989, Wassmann et al. 1990, 1994, Wassmann \& Slagstad 1993). The studies were part of the extensive oceanographic investigations carried out in the Barents Sea by the Norwegian

·E-mail: ingera@nfh.uit.no
Research Programme for Marine Arctic Ecology (PRO MARE) (e.g. Sakshaug et al. 1991).

Previous studies of vertical flux in the Barents Sea had low vertical resolution and were only to a limited degree conducted in concert with studies of pelagic processes. Our knowledge of the relative contribution of algal groups to the vertical export of carbon and of the environmental and biological factors that control their abundance is therefore limited, in particular in the marginal ice zone (MIZ). Studies of vertical flux from the ice-covered waters east and north off Spitsbergen are even more scarce (Andreassen et al. 1996). Therefore, based on current knowledge, a field program to study phytoplankton abundance and vertical export of biogenic matter from the upper layers of the MIZ and the central Barents Sea was carried out in concert with 
studies of other pelagic processes (Hansen et al. 1996 , Urban-Rich 1997, Vernet et al. 1998, Wassmann et al. 1998). A section ranging from $72^{\circ} 30^{\prime} \mathrm{N}$ to $80^{\circ} \mathrm{N}$ in the central Barents Sea was emphasised in earlier studies (e.g. Skjoldal et al. 1987, Wassmann \& Slagstad 1993) and the same section was chosen for this study. The transect crosses the zonal structure of the Barents Sea and its main water masses: Atlantic water, the Polar Front, the ice edge and Arctic water.

The Barents Sea is characterised by a complex hydrography with large regional differences in hydrographic conditions and ice coverage (Rey \& Loeng 1985, Loeng 1991). The environment is highly dynamic both on a seasonal and interannual scale (Wassmann et al. 1996) and physical processes strongly influence the pelagic community both in terms of production and species composition. The magnitude of the vertical flux is determined by new production, phytoplankton bloom development and species composition as well as the impact of planktonic heterotrophs on algae. The physical oceanography may hence influence the dynamics of the vertical flux in the Barents Sea indirectly through its impact on ice coverage, ice melt, stabilisation, and through over-wintering, advection and retention of zooplankton (Wassmann et al. 1996).

The spring bloom in the MIZ of the Barents Sea usually starts in April/May, when the ice begins to retreat (Rey \& Loeng 1985). Normally, the bloom takes place earlier and develops more rapidly in the MIZ than in the central Barents Sea, which is dominated by Atlantic water. Bloom development in the central part of Barents Sea usually takes place in May/June. Phytoplankton growth starts earlier, but stabilisation of the water column by solar radiation is slow, and hence the increase in phytoplankton biomass is correspondingly delayed (Rey \& Loeng 1985).

Lack of a strong grazing impact by herbivorous mesozooplankton during spring in the Barents Sea gave rise to the hypothesis that extensive sedimentation of ungrazed phytoplankton and phytodetritus may take place at the end of the spring bloom (Eilertsen et al. 1989, Wassmann et al. 1990, Wassmann \& Slagstad 1993). An increase in herbivorous mesozooplankton standing stock, due to advection of copepodites from the Norwegian Sea (Pedersen et al. 1995), is believed to reduce the pulse of spring sedimentation, compared to years with less herbivores (Wassmann \& Slagstad 1993). Macrozooplankton such as euphausiids are important in the Barents Sea (Dalpadado \& Skjoldal 1991), but little is known of their impact on the phytoplankton dynamics in the area. Recently, microzooplankton grazing has also been shown to be important and may exceed the grazing pressure of copepods during spring in the central and northern Barents Sea (Hansen et al. 1996).
A detailed description of hydrography, nutrient concentrations and phytoplankton community along the transect about 1 wk prior to this study is presented in (Wassmann et al. 1998). Primary production, grazing, faecal pellet production and faecal pellet vertical flux investigated parallel to this study are presented elsewhere (Hansen et al. 1996, Urban-Rich 1997, Vernet et al. 1998). Here we present information on the hydrography, nutrients, phytoplankton community and vertical flux of biogenic matter and microplankton at 4 stations in the northern and central Barents Sea. The intention of this investigation is to increase knowledge about the relative contribution of algal groups to the vertical export of carbon and to address possibly important processes in the regulation of vertical flux of phytoplankton and biogenic matter in the Barents Sea.

\section{MATERIAL AND METHODS}

Data were collected during a cruise to the Barents Sea onboard RV 'Jan Mayen' during spring 1993. The sampling period was May 19-26; data was collected while returning southward along a transect in the central Barents Sea (described by Wassmann et al. 1998). The sampling area was from $76^{\circ} 22^{\prime} \mathrm{N}, 32^{\circ} 44^{\prime} \mathrm{E}$ to $73^{\circ} 40^{\prime} \mathrm{N}, 30^{\circ} 35^{\prime} \mathrm{E}$ (Fig. 1).

Vertical flux data were collected using drifting sediment traps. In ice-covered areas it was necessary to anchor the drifter to ice floes to prevent the surface buoy from submerging under the ice during the drift. Free drifting sediment traps are convenient tools for short studies ( 1 to $2 \mathrm{~d}$ ) of vertical flux since they are easily deployed and allow to some extent tracking of water masses. Turbulence around the opening of the trap due to strong currents may severely bias the estimation of both quality and quantity of settling matter. This problem is reduced when sediment traps are allowed to drift (Staresinic et al. 1978, GOFS 1989, Bloesch 1997). However, ice drift and surface currents may have different directions than deeper water currents. Sampling of vertical flux at all stations may thus be biased by current shear.

Sediment traps were deployed at 4 stations along the transect (Table 1). Vertical flux of particulate organic material was collected with 9 sediment traps between 20 and $100 \mathrm{~m}$ and 5 sediment traps every $20 \mathrm{~m}$ between 100 and $200 \mathrm{~m}$. The sediment traps (KC maskiner og laboratorieudstyr, Denmark) were parallel cylinders mounted in a gimballed frame equipped with a vane to ensure that the cylinders were always positioned vertically and never shaded each other. The traps were $0.072 \mathrm{~m}$ in diameter and $0.45 \mathrm{~m}$ high $(\mathrm{H} / \mathrm{D}$ ratio $=6.25$ ). The traps were deployed for 36 to $38 \mathrm{~h}$. 


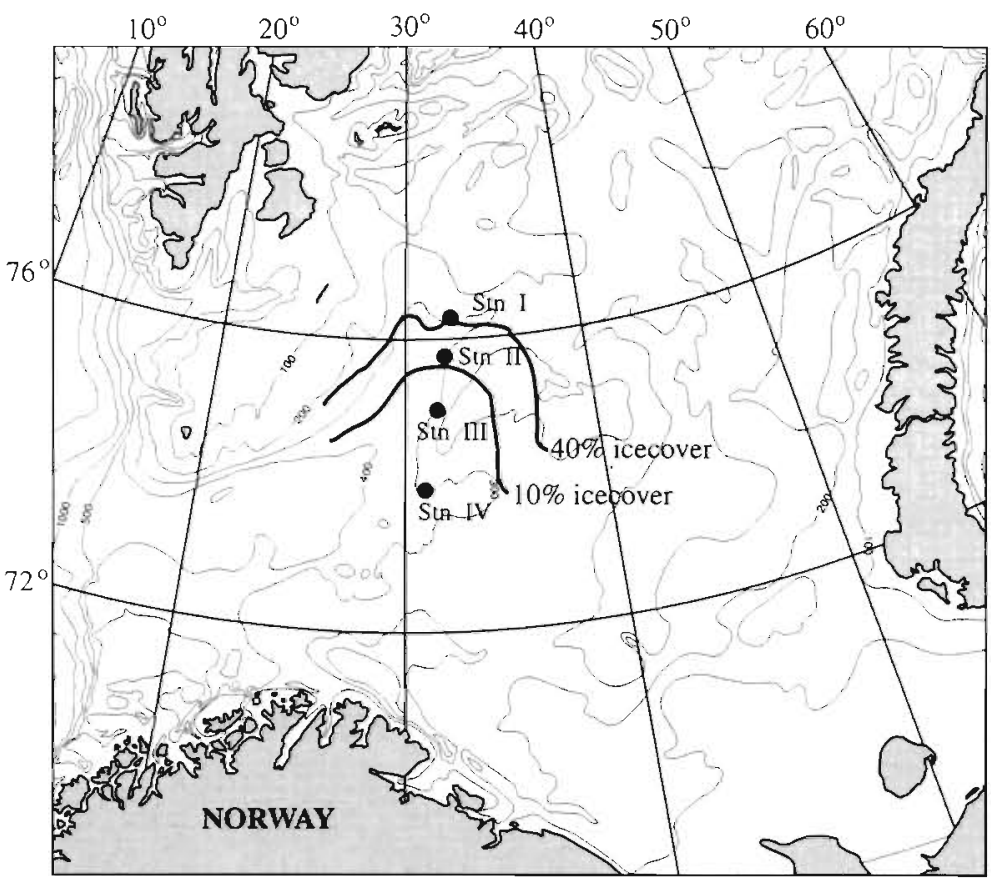

Fig. 1. Map of the sampling area in the Barents Sea with positions of stations and ice coverage in the area

Poison was not applied and, therefore, grazing and bacterial decomposition could have taken place in the sediment traps during the deployment.

While following the drifter, CTD profiles and samples for pigment analysis were taken every $6 \mathrm{~h}$. Hydrographic profiles were obtained by means of a Neil Brown Mk III CTD profiler mounted together with a SeaTech fluorometer, and a General Oceanic Rosette Sampler equipped with 51 Niskin bottles. Samples for nutrients, chlorophyll $a$ (chl a) and phaeopigments (phaeo) and microscopic examination of phytoplankton were taken at selected depths based on irradiance $(50,30,10,1$ and $0.1 \%$ surface irradiance) and the structure of other physical or biological parameters of the water column (e.g. fluorescence maximum or stratification). Samples for chl $a$ and phaeo were filtered on precombusted Whatman GF/F filters. Samples for microscopic examination were fixed with an ethanolglutaraldehyde-Lugol solution (Rousseau et al. 1990)

Table 1. Date of deployment and positions of deployment and recovery of drifting sediment traps in May 1993 in the Barents Sea

\begin{tabular}{|lccc|}
\hline Stn & Date & Deployment & Recovery \\
\hline I & May 19 & $32^{\circ} 44^{\prime} \mathrm{E}, 76^{\circ} 22^{\prime} \mathrm{N}$ & $31^{\circ} 26^{\prime} \mathrm{E}, 76^{\circ} 20^{\prime} \mathrm{N}$ \\
II & May 21 & $32^{\circ} 30^{\prime} \mathrm{E}, 75^{\circ} 58^{\prime} \mathrm{N}$ & $31^{\circ} 58^{\prime} \mathrm{E}, 75^{\circ} 53^{\prime} \mathrm{N}$ \\
III & May 23 & $31^{\circ} 42^{\prime} \mathrm{E}, 74^{\circ} 58^{\prime} \mathrm{N}$ & $31^{\circ} 31^{\prime} \mathrm{E}, 75^{\circ} 04^{\prime} \mathrm{N}$ \\
IV & May 25 & $31^{\circ} 00^{\prime} \mathrm{E}, 73^{\circ} 44^{\prime} \mathrm{N}$ & $30^{\circ} 35^{\prime} \mathrm{E}, 73^{\circ} 40^{\prime} \mathrm{N}$ \\
\hline
\end{tabular}

especially designed to preserve Phaeocystis sp. colonies. Samples for nitrate, silicate and phosphate were handled and analysed by a Technicon autoanalyser as described by Wassmann (1991b) at the Institute of Marine Research, Bergen, Norway.

After recovery, contents of the sediment traps were transferred to bottles and kept cold and dark. Samples were never kept more than 6 h before subsampling. Each sample was thoroughly mixed and a bird pipette was used for subsampling. Duplicate samples (200 to $300 \mathrm{ml}$ ) from each cylinder were taken and filtered for analysis of particulate organic carbon and nitrogen (POC and PON), chl $a$ and phaeo on precombusted Whatman GF/F filters. On all filters, swimmers were removed by means of forceps. Samples for microscopic examination were taken from the traps deployed at 60,100 and $200 \mathrm{~m}$.

Samples for chl a and phaeo were analysed immediately after subsampling using a Turner Design AU-10 fluorometer according to Holm-Hansen et al. (1965).

POC and PON samples were stored in a freezer $\left(-18^{\circ} \mathrm{C}\right)$ and were later analysed on a Leeman Lab CEC $440 \mathrm{CHN}$ analyser after removal of carbonate with fumes of concentrated $\mathrm{HCl}$.

Aliquots of $10 \mathrm{ml}$ for sediment trap samples and $25 \mathrm{ml}$ for water samples were allowed to settle for $24 \mathrm{~h}$, before examination in a Leitz DM IL inverted microscope. A minimum of 50 to 100 cells of the dominant phytoplankton species or groups in the samples were counted. When one or a few species dominated the sample, cells were quantified at a species level, but most cells were counted in classes at higher taxonomic levels. Average cell size of each group was measured to calculate the carbon content of the cells (PPC), according to Strathmann (1967). The carbon content of colonial Phaeocystis sp. was calculated in 2 steps. The carbon content of the colonial matrix was calculated according to Rousseau et al. (1990). Carbon content of the cells in the colonies was calculated by using average cell numbers for different size classes of colonies (estimated by counting colonial cells in 10 colonies from each size class). Diatoms are presented in groups of families, other groups at a class or subclass level. It was not always possible to distinguish between autotrophic and heterotrophic dinoflagellates and flagellates, which implies that groups of autotrophic dinoflagellates and flagellates also included heterotrophic cells.

Daily loss rates (\%) were calculated using integrated concentrations of chl a from 0 to $30 \mathrm{~m}$ and 0 to $60 \mathrm{~m}$ 


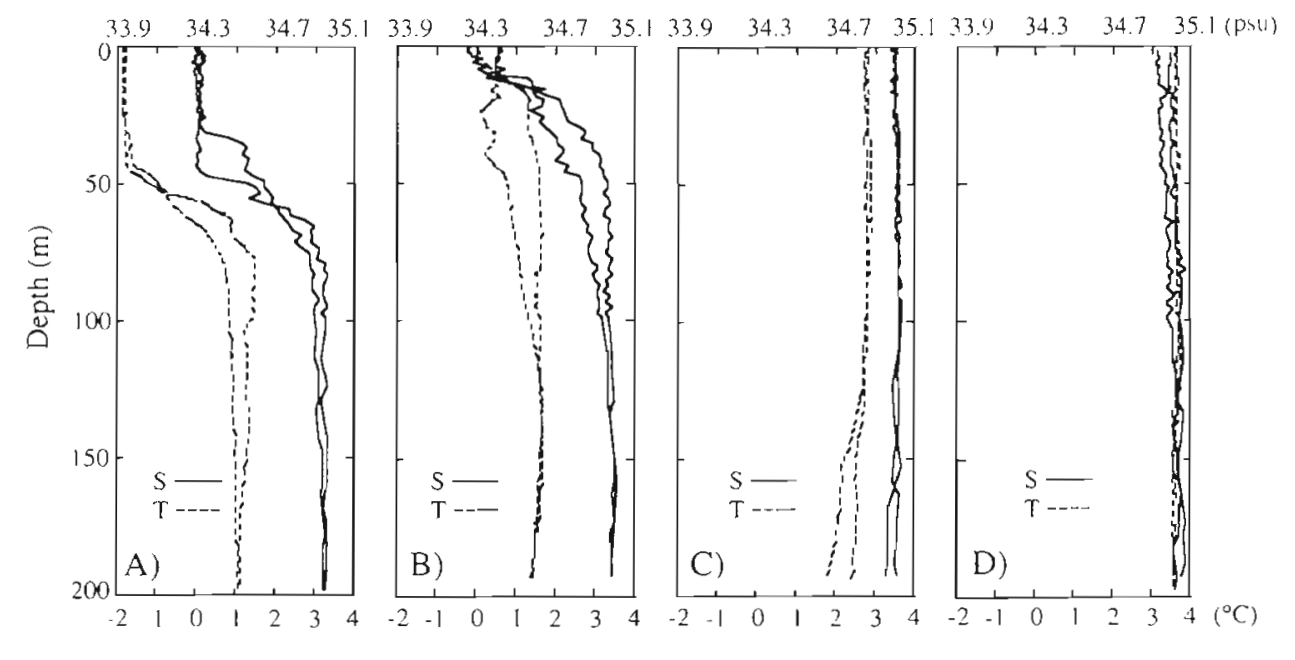

Fig. 2. Vertical profiles of temperature $(\mathrm{T})$ and salinity (S) at the time of deployment and recovery of sediment traps at (A) Stn I, (B) Stn II

(C) Stn III. (D) Stn IV (averages based on 4 to 6 profiles taken during drift) and PPC from 0 to $60 \mathrm{~m}$ divided by the vertical fluxes of chl $a$ at 30 and $60 \mathrm{~m}$ depth and PPC at $60 \mathrm{~m}$.

\section{RESULTS}

\section{Ice coverage and hydrography}

Stns I and II were located in the MIZ close to the Polar Front. Stn I had 40 to $60 \%$ ice coverage (Fig. 1) and the surface water was characterised by fresh and cold Arctic water ( $34.32 \mathrm{psu}$ and $<-1.7^{\circ} \mathrm{C}$ ) down to 40-50 $\mathrm{m}$ (Fig. 2A). Below $50 \mathrm{~m}$ warmer and more saline water $\left(34.60\right.$ to 34.95 psu and 1 to $1.5^{\circ} \mathrm{C}$ ) of probable Atlantic origin dominated. The depth of the halocline varied during the time of drift. Stn II had $\sim 40 \%$ ice coverage (Fig. 1) at the time when the sediment trap was deployed, but the ice coverage was reduced during the time of deployment to $-20 \%$. The surface water at Stn II was characterised by warmer water ( 0 to $1.5^{\circ} \mathrm{C}$ ) with a similar salinity $(34.33$ psu) as Stn I (Fig. 2B). The upper layer was thinner (20 to $40 \mathrm{~m}$ ) than at Stn I. Profiles of salinity and temperature changed during the period of drift The upper 10 to $15 \mathrm{~m}$ became more homogeneous and the water below the pycnocline showed a decrease in temperature and salinity during this period, indicating vertical mixing.

Stns III and IV were not influenced by sea ice and were dominated by Atlantic water $\left(2.5\right.$ to $3^{\circ} \mathrm{C}$ and $-35 \mathrm{psu}$ ). The water column of the 2 stations did not have any distinct stratification, but both stations had a slight increase of density from surface to $100 \mathrm{~m}$ (Fig. 2C, D) While there was no significant change in the temperature and salinity during the drift at Stn III, a slight increase of salinity during the drift at Stn IV was recorded (Fig 2D).

\section{Nutrients and pigments}

The lowest nutrient concentrations during this investigations were found in the upper $40 \mathrm{~m}$ at $\mathrm{Stn} I$ (Fig 3B). The concentration of $\mathrm{Si}(\mathrm{OH})_{4}$ was close to detection limit $(\sim 0.1 \mu \mathrm{M})$, while nitrate and phosphate concentrations were higher $(>2 \mu \mathrm{M} \mathrm{NO} 3$ and $>0.3 \mu \mathrm{M}$ $\mathrm{PO}_{4}$ ). Below the pycnocline nutrients were close to winter concentrations (about 10,5 and $0.8 \mu \mathrm{M}$ of $\mathrm{NO}_{3}$, $\mathrm{Si}(\mathrm{OH})_{4}$ and $\mathrm{PO}_{4}$, respectively). High concentrations of $\mathrm{chl} \mathrm{a}\left(12.6\right.$ to $\left.14.6 \mathrm{mg} \mathrm{m}^{-3}\right)$ were also observed in the upper 40 to $50 \mathrm{~m}$ at Stn I (Fig. 3C). Stn IJ had much lower chl a concentrations and a sub-surface maximum (2.7 to $3.3 \mathrm{mg} \mathrm{m}^{-3}$ ) at the depth of the pycnocline (Fig. 4A, C) was observed. Nutrient concentrations at Stn II [data from the start of the drift: $>4 \mu \mathrm{M} \mathrm{NO}_{3}$ and $\left.>2.6 \mu \mathrm{M} \mathrm{Si}(\mathrm{OH})_{4} ; \mathrm{Fig} .4 \mathrm{~B}\right]$ were higher in the upper water column compared to Stn I, but nutrient concentrations were reduced during the drift $\left[2\right.$ to $3 \mu \mathrm{M} \mathrm{NO}_{3}$ and 0.8 to $\left.2.1 \mu \mathrm{M} \mathrm{Si}(\mathrm{OH})_{4}\right]$. Nutrient concentrations below the pycnocline at Stn II ( 35 to $45 \mathrm{~m}$ ) were also reduced compared to winter. values (Fig $4 \mathrm{~B}$ ). The highest nutrient concentrations in the upper water column during this investigation were observed at Stn III $\left[>6 \mu \mathrm{M} \mathrm{NO} 3\right.$ and $>3 \mu \mathrm{M} \mathrm{Si}(\mathrm{OH})_{4} ;$ Fig. 5B]. Stn IV had lower nutrient concentrations $\left[3.8\right.$ to $6 \mu \mathrm{M} \mathrm{NO}_{3}$ and 0.9 to $1.4 \mu \mathrm{M} \mathrm{Si}(\mathrm{OH})_{4}$; Fig. $6 \mathrm{~B}$ ]. The chl a profiles showed modest concentrations (1.1 to $2.4 \mathrm{mg} \mathrm{m}^{-3}$ ) above $50 \mathrm{~m}$ at both Stns III and IV (Figs. 5C \& 6C).

\section{Suspended phytoplankton}

The phytoplankton community of Stn. I (Fig. 7A) was characterised by high abundance of penrlate ribbonforming species (Fragilariopsis sp. and Navicula spp., total: $3 \times 10^{5}$ to $1.1 \times 10^{6}$ cells $1^{-1}$ ) and colony-forming 


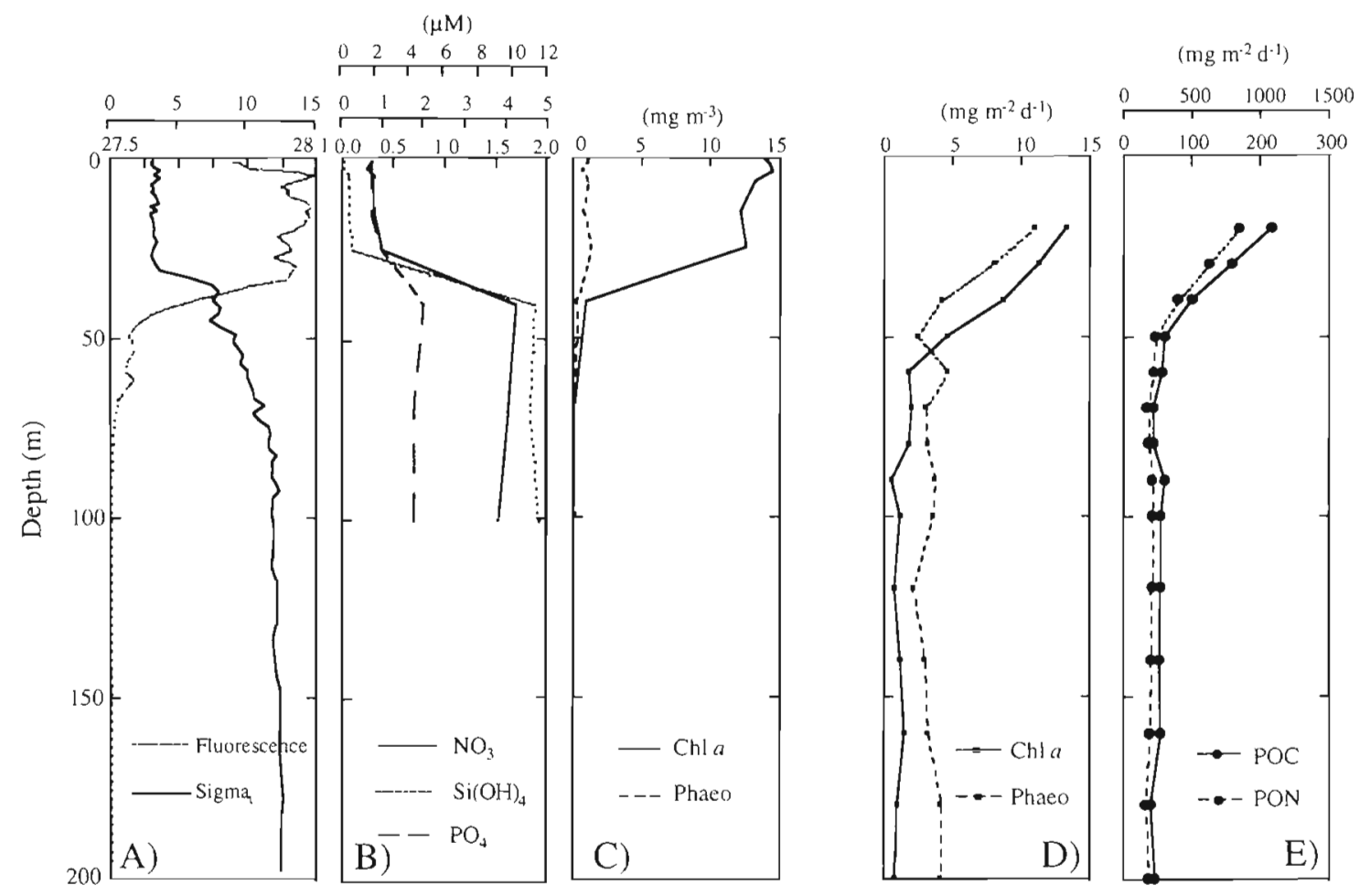

Fig. 3. Profiles from Stn I of (A) fluorescence (upper axis) and sigma-t (lower axis); (B) nutrient concentrations of $\mathrm{NO}_{3}$ (upper axis), $\mathrm{Si}(\mathrm{OH})_{4}$ (middle axis) and $\mathrm{PO}_{4}$ (lower axis); (C) suspended chl a and phaeopigment; (D) vertical flux of chl a and phaeopigments and (E) vertical flux of POC (upper axis) and PON (lower axis). Profiles in $\mathrm{A}$ to $\mathrm{C}$ are representative of average conditions
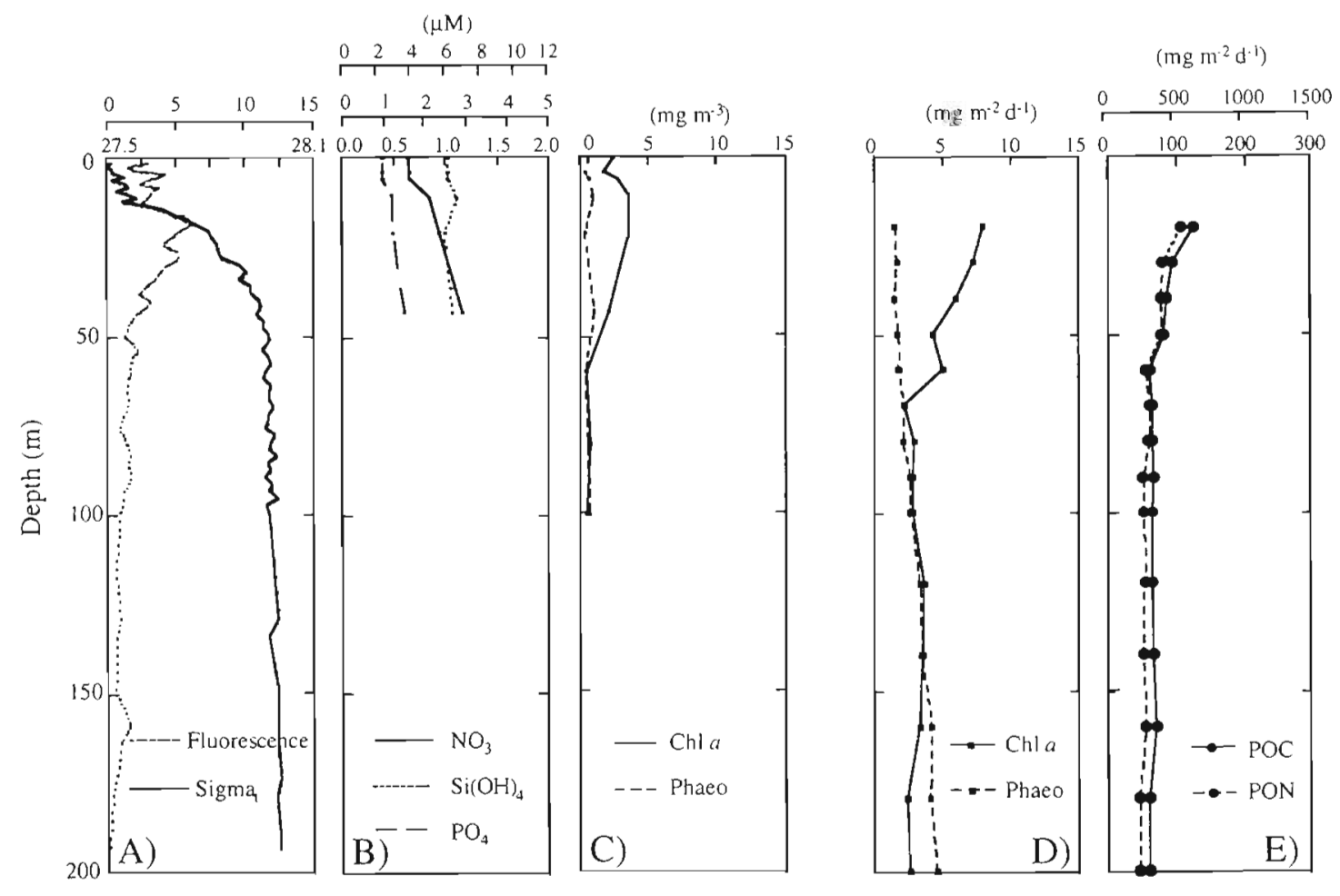

Fig. 4. Profiles from Stn II of (A) fluorescence (upper axis) and sigma-t (lower axis); (B) nutrient concentrations of $\mathrm{NO}_{3}$ (upper axis), $\mathrm{Si}(\mathrm{OH})_{4}$ (middle axis) and $\mathrm{PO}_{4}$ (lower axis); (C) suspended chl a and phaeopigment; (D) vertical flux of chl $a$ and phaeopigments and (E) vertical flux of POC (upper axis) and PON (lower axis). Profiles in $A$ to $C$ are representative of average conditions 


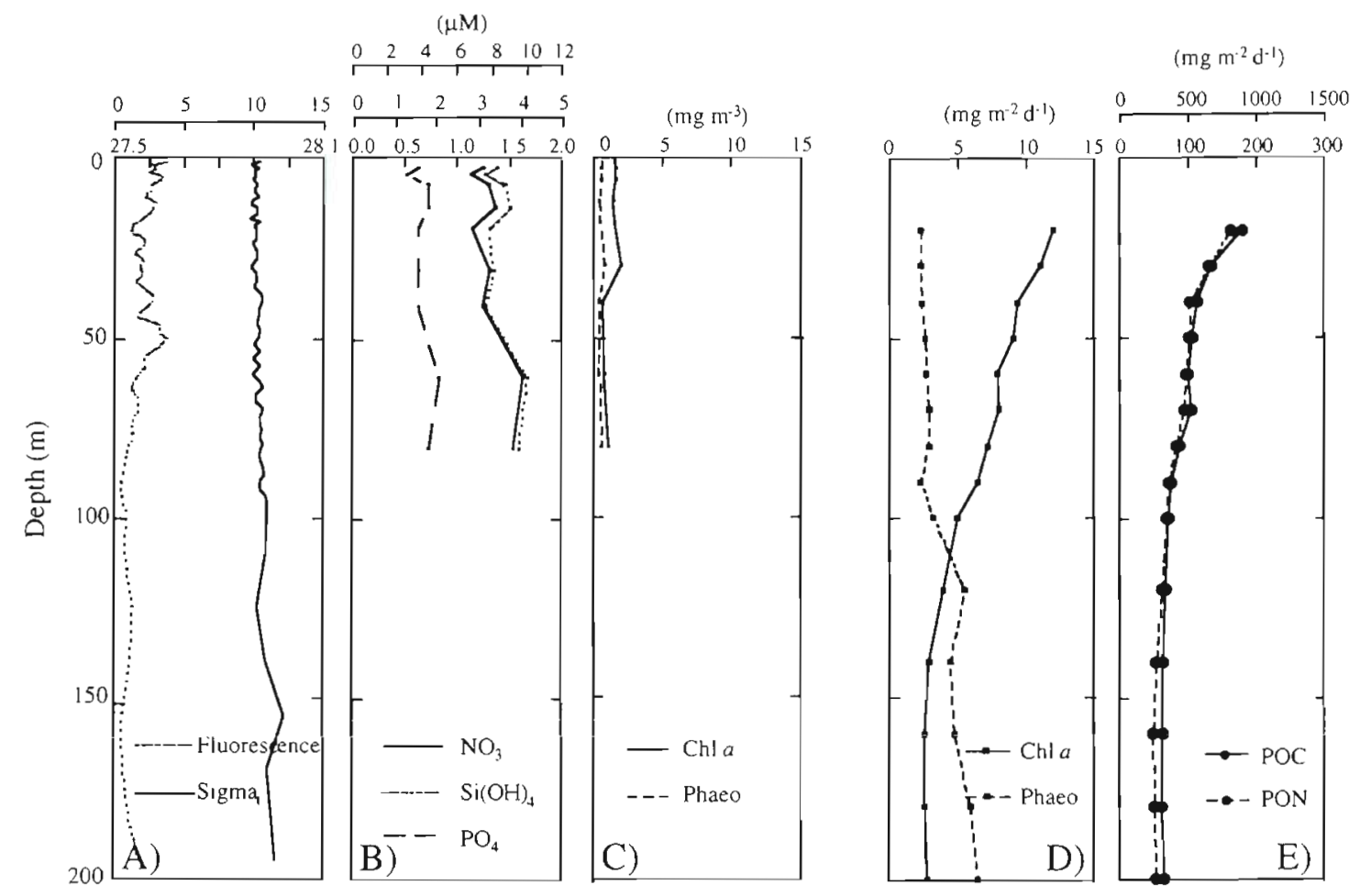

Fig. 5. Profiles from Stn III of (A) fluorescence (upper axis) and sigma-t (lower axis); (B) nutrient concentrations of $\mathrm{NO}_{3}$ (upper axis), $\mathrm{Si}(\mathrm{OH})_{4}$ (middle axis) and $\mathrm{PO}_{4}$ (lower axis); (C) suspended chl a and phaeopigment; (D) vertical flux of chl $a$ and phaeopigments and (E) vertical flux of POC (upper axis) and PON (lower axis). Profiles in A to $\mathrm{C}$ are representative of average conditions

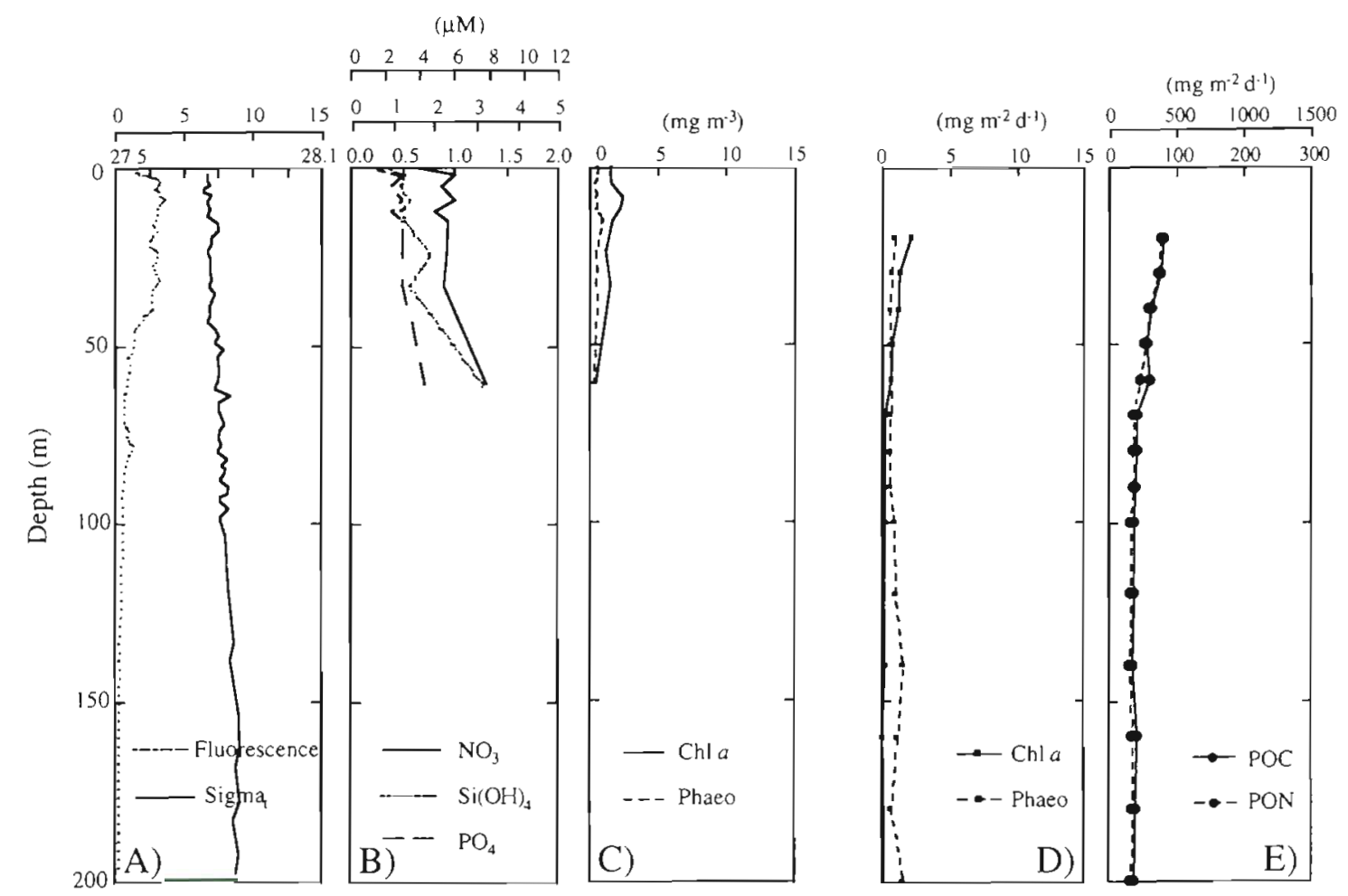

Fig. 6. Profiles from Stn IV of (A) fluorescence (upper axis) and sigma-t (lower axis); (B) nutrient concentrations of $\mathrm{NO}_{3}$ (upper axis), $\mathrm{Si}(\mathrm{OH})_{4}$ (middle axis) and $\mathrm{PO}_{4}$ (lower axis); (C) suspended chl a and phaeopigment; (D) vertical flux of chl a and phaeopigments and (E) vertical flux of $\mathrm{POC}$ (upper axis) and PON (lower axis). Profiles in $\mathrm{A}$ to $\mathrm{C}$ are representative of average conditions 
Fig. 7 Distribution of microplankton carbon at (A) Stn I, (B) Stn II, (C) Stn III, (D) Stn IV

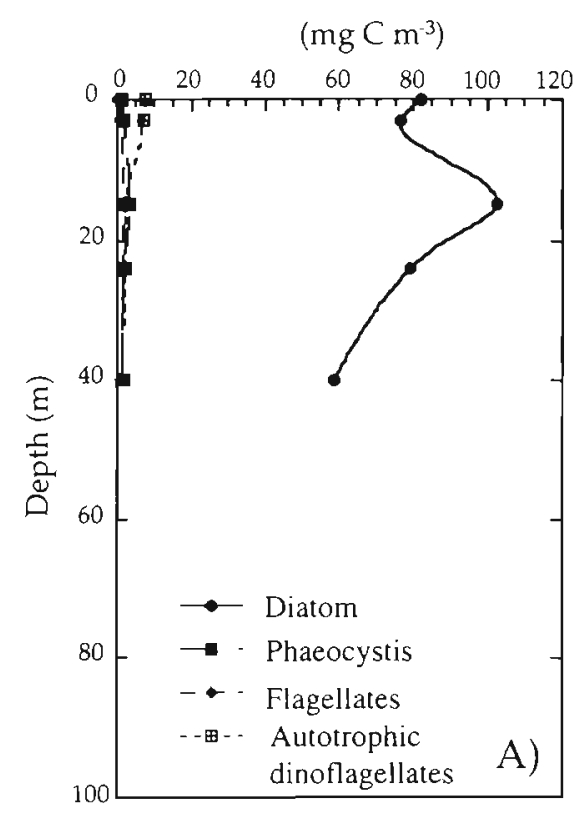

$\left(\mathrm{mgC} \mathrm{m} \mathrm{m}^{-3}\right)$

$\left.(\mathrm{mgC} \mathrm{m})^{-3}\right)$

(mg C m-3)
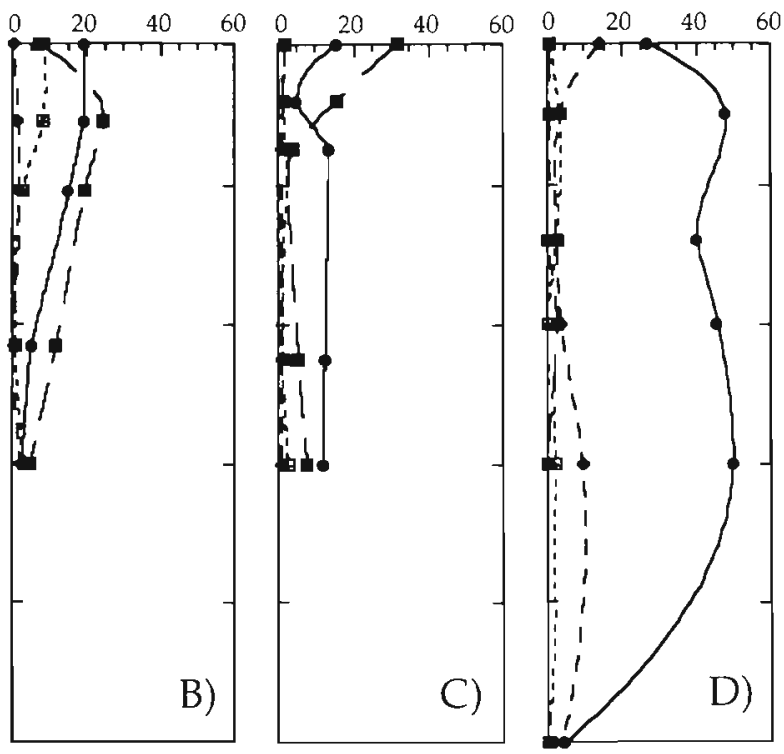

centric diatoms (Chaetoceros spp. and Thalassiosira spp., total: $>4.2 \times 10^{6}$ cells $\mathrm{l}^{-1}$ ). Only a few Phaeocystis sp. colonies were observed, equivalent to $<3 \%$ of total PPC. Except for the surface water, Phaeocystis sp. $(\sim 4.3$ $\times 10^{4}$ colonies $\mathrm{l}^{-1}$ ) dominated the water column at Stn II (Fig. 7B) and made up 38 to $67 \%$ of the PPC below $10 \mathrm{~m}$. Chaetoceros spp. and Thalassiosira spp. were the dominant diatoms (total cell numbers: 1.5 to $2.0 \times$ $10^{6}$ cells l$^{-1}$ ) above $20 \mathrm{~m}$ at Stn II. At Stn III (Fig. 7C) the PPC maximum was found in the upper water column 10 to $8 \mathrm{~m}$ depth). Phaeocystis sp. colonies (1.2 to $2.9 \times 10^{3}$ colonies $\mathrm{l}^{-1}$ ) provided $>60 \%$ of PPC. Below $8 \mathrm{~m}$, Thalassiosira spp. became the dominant phytoplankton group in terms of biomass at Stn III. The phytoplankton at Stn IV (Fig. 7D) was dominated by Chaetoceros spp. both in numbers ( 2.0 to $2.5 \times 10^{5}$ cells $\mathrm{l}^{-1}$ ) and biomass. The phytoplankton concentration was nearly uniform throughout the water column down to $60 \mathrm{~m}$, and a decline in phytoplankton concentration was recorded between 60 and $100 \mathrm{~m}$ depth. Only a few Phaeocystis sp. colonies were found in the water column $(<4.0 \times$ $10^{2}$ colonies $\mathbf{l}^{-1}$ ).

\section{Vertical flux of particulate biogenic matter}

For all stations, the vertical flux of POC, PON and chl a was highest in the upper water column; this vertical flux decreased with increasing depth in the upper water column (D \& E of Figs. 3 to 6 ). The main decrease in the POC, PON and chl $a$ vertical flux at Stn I was in the water column above $60 \mathrm{~m}$ and at Stns II and IV above $70 \mathrm{~m}$. The vertical flux of POC, PON and chl a at Stn III decreased steadily from 20 to $140 \mathrm{~m}$ depth.
Below these depths there was no significant decrease or increase in the vertical flux of POC, PON and chl a.

The vertical flux of chl a was highest in the upper water column at Stns I and III (13.3 and $12 \mathrm{mg} \mathrm{chl} \mathrm{a} \mathrm{m}^{-2}$ $\mathrm{d}^{-1}$, respectively, at $20 \mathrm{~m}$; Figs. 3D \& 5D). Stn II had

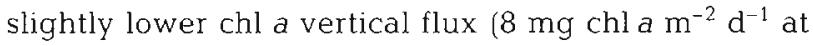
$20 \mathrm{~m}$; Fig. 4D) and the lowest flux of chl a was found at Stn IV (2.1 $\mathrm{mg} \mathrm{chl} \mathrm{a} \mathrm{m}^{-2} \mathrm{~d}^{-1}$ at $20 \mathrm{~m}$; Fig, 6D). Vertical flux of POC was 1090 and $880 \mathrm{mg} \mathrm{C} \mathrm{m}^{-2} \mathrm{~d}^{-1}$ at $20 \mathrm{~m}$, respectively, at Stns I and III (Figs. 3E \& 5E), $620 \mathrm{mg}$ $\mathrm{m}^{-2} \mathrm{~d}^{-1}$ at Stn II at $20 \mathrm{~m}$ (Fig. $4 \mathrm{E}$ ) and $410 \mathrm{mg} \mathrm{C} \mathrm{m}^{-2} \mathrm{~d}^{-1}$ at Stn IV at $20 \mathrm{~m}$ (Fig. 6E).

The vertical flux of phaeo was shown to be different from the POC and chl a vertical flux. At Stn I the vertical flux of phaeo (Fig. 3D, E) at $20 \mathrm{~m}$ was high $(11 \mathrm{mg}$ $\mathrm{m}^{-2} \mathrm{~d}^{-1}$ ), but decreased with depth to $2.5 \mathrm{mg} \mathrm{m}^{-2} \mathrm{~d}^{-1}$ at $50 \mathrm{~m}$. The vertical flux of phaeo was low in the upper water column at the other 3 stations $\left(<3 \mathrm{mg} \mathrm{m}^{-2} \mathrm{~d}^{-1}\right.$ above $100 \mathrm{~m}$; D of Figs. 3-5), but increased slightly with depth. Pigment composition of the exported matter changed from chl a $>$ phaeo in the upper water column to chl a < phaeo below $60 \mathrm{~m}$ at Stns I and IV (Figs. 3D \& 6D), below $70 \mathrm{~m}$ at Stn II (Fig. 4D) and below $100 \mathrm{~m}$ at Stn III (Fig. 5D).

\section{Vertical flux of microplankton}

The species composition of the sinking microplankton at $60 \mathrm{~m}$ was mainly similar to the species composition observed in the water column above the traps. Vertical flux of microplankton generally decreased with increasing depth, though some differences between groups were observed. 

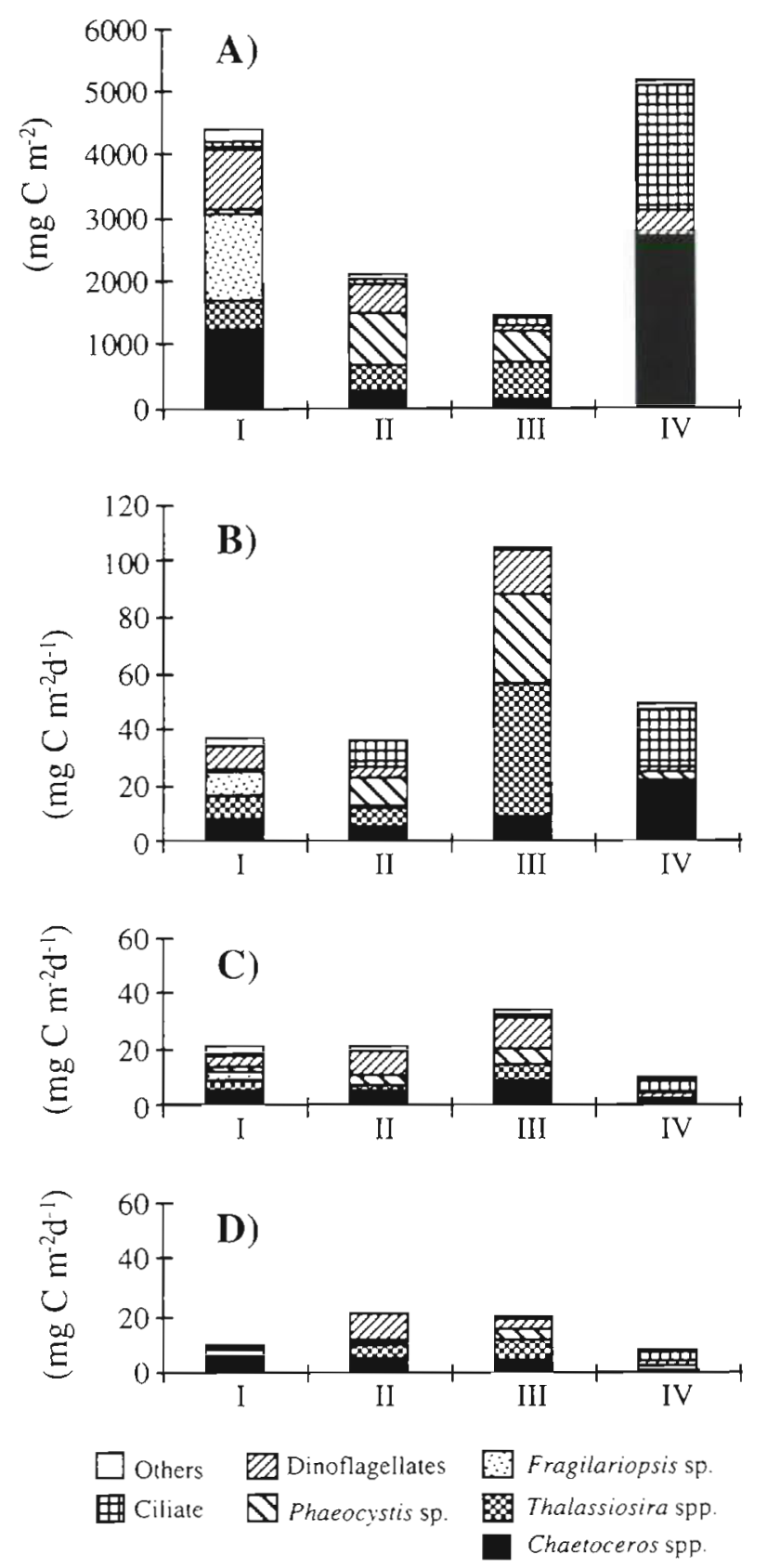

Fig. 8. (A) Integrated phytoplankton carbon from 0 to $40 \mathrm{~m}$ at Stn I and 0 to $60 \mathrm{~m}$ at Stns II, IIII, and IV. (B-D) Vertical flux of phytoplankton carbon at 60,100 and $200 \mathrm{~m}$, respectively

At Stn I the vertical flux of diatoms decreased with increasing depth from 26 to $9 \mathrm{mg} \mathrm{C} \mathrm{m}^{-2} \mathrm{~d}^{-1}$ at $60 \mathrm{~m}$ and $200 \mathrm{~m}$, respectively. While the vertical flux of Thalassiosira spp. decreased with increased depth throughout the water column, the vertical flux of Chaetoceros spp. and Fragilariopsis sp. was not significantly different at 100 and $200 \mathrm{~m}$ depth (Fig. 8C, D). The vertical flux of diatoms at $60 \mathrm{~m}$ depth was more than 4 times higher at Stn III than at Stn. II (56 and $13 \mathrm{mg} \mathrm{C} \mathrm{m}^{-2} \mathrm{~d}^{-1}$, respectively). At Stn III the vertical flux of Thalassiosira spp. decreased substantially between 60 and $100 \mathrm{~m}$ depth, and at $200 \mathrm{~m}$ depth the vertical flux of diatoms was similar at Stns II and III (10 and $11 \mathrm{mg} \mathrm{C}$ $\mathrm{m}^{-2} \mathrm{~d}^{-1}$, respectively; Fig. 8D). The vertical flux of diatoms at $60 \mathrm{~m}$ at Stn IV was comparable to that at Stn I, but the rate decreased substantially from 60 to $100 \mathrm{~m}$ depth and diatoms were not important for the flux at 100 and $200 \mathrm{~m}$ depth.

Phaeocystis $\mathrm{sp}$. colonies were not important for the vertical flux of PPC at Stns I and IV, but colonies were found in the traps at all depths. The highest vertical flux of Phaeocystis sp. colonies was observed at Stns II and III $\left(2.67 \times 10^{6}\right.$ and $1.75 \times 10^{6}$ colonies $\mathrm{m}^{2} \mathrm{~d}^{-1}$ at $60 \mathrm{~m}$, respectively). The vertical flux of Phaeocystis sp. carbon decreased between 60 and $100 \mathrm{~m}$ at both Stns II and III (Fig. 8), but the decrease was mainly due to smaller colony size and fewer cells in the colonies and not a decrease in number of sinking colonies. All Phaeocystis sp. colonies at 100 and $200 \mathrm{~m}$ depth at Stns II and III were senescent, and at $200 \mathrm{~m}$ Phaeocystis sp. colonies were difficult to recognise. Only a few Phaeocystis sp. cells were left in the colonial matrix, and phytodetritus, diatoms, ciliates and dinoflagellates were associated. In addition to the senescent colonies, aggregates of probable Phaeocystis sp. origin were found at 100 and $200 \mathrm{~m}$ depth. The number of sinking colonies/aggregates of Phaeocystis sp. was similar at 100 and $200 \mathrm{~m}$. Fig. 8 includes only material that has been positively identified as Phaeocystis sp. due to remaining cells in the matrix.

At all stations large dinoflagellates and ciliates, probably heterotrophic, were important for the vertical flux of PPC at $60 \mathrm{~m}$ in terms of biomass, especially at Stn IV. Generally the vertical flux of protozoa decreased with increasing depth. Dinoflagellates and ciliates were often associated to aggregates in the deepest traps.

\section{Daily loss rates of $\mathrm{chl} \mathbf{a}$ and phytoplankton}

Stns II and III had the highest daily loss rates of chl a standing stock recorded during this investigation. Loss rates at Stn III were $18 \%$ at $30 \mathrm{~m}$ and $8 \%$ at $60 \mathrm{~m}$ while at Stn II daily loss rates of chl a were $10 \%$ at $30 \mathrm{~m}$ and $4 \%$ at $60 \mathrm{~m}$ (Table 2). Daily loss rates of chl a at Stn IV were $1.6 \%$ at $30 \mathrm{~m}$ and decreased to $0.6 \%$ of standing stock at $60 \mathrm{~m}$ (Table 2). Daily loss rates of chl a at Stn I were $3.5 \%$ at $30 \mathrm{~m}$ and decreased to $0.4 \%$ of standing stock at $60 \mathrm{~m}$.

Daily loss rates of microplankton at Stn I were in the range 0.4 to $1.7 \%$ at $60 \mathrm{~m}$, with highest daily loss rates for Phaeocystis sp. and Thalassiosira spp. (Table 2). At Stn II ciliates experienced the highest daily loss rate 
Table 2. Daily loss rates of chl a at 30 and $60 \mathrm{~m}$ and daily loss rates of 6 different microplankton groups at $60 \mathrm{~m}$ at the 4 stations

\begin{tabular}{|lcccc|}
\hline $\begin{array}{l}\text { Daily loss rate } \\
\left(\% \mathrm{~d}^{-1}\right)\end{array}$ & I & II & IIl & IV \\
\hline Chl a $(30 \mathrm{~m})$ & 3.5 & 10.2 & 18.4 & 1.6 \\
Chl a $(60 \mathrm{~m})$ & 0.4 & 4.0 & 7.7 & 0.6 \\
$\begin{array}{l}\text { Pennate chain- } \\
\quad \text { forming diatoms }\end{array}$ & 0.6 & - & - & - \\
Phaeocystis sp. & 1.5 & 1.2 & 6.7 & 5.2 \\
Chaetoceros spp. & 0.6 & 1.9 & 7.4 & 0.8 \\
Thalassiosira spp. & 1.7 & 1.7 & 8.3 & 3.4 \\
Dinoflagellates & 0.8 & 1.1 & 13.0 & 0.4 \\
Ciliates & 0.4 & 8.7 & - & 1.1 \\
\hline
\end{tabular}

with $8.7 \%$, the other microplankton groups had daily loss rates in the range 1.1 to $1.9 \%$ (Table 2 ). The highest daily loss rates of microplankton during this investigation was observed at Stn III with $13 \%$ of dinoflagellates and 6.7 to $8.3 \% \mathrm{~d}^{-1}$ loss of Phaeocystis sp., Chaetoceros spp. and Thalassiosira spp. At Stn IV Phaeocystis sp. had the highest daily loss rates at $60 \mathrm{~m}$ with $5.2 \%$ and Thalassiosira spp. also had a relatively high daily loss rate with $3.4 \%$. Daily loss rates for the remaining microplankton groups at Stn IV (Table 2) ranged between 0.4 and $1.1 \%$.

\section{DISCUSSION}

The vertical profiles of temperature and salinity (Fig. 2) show that the characteristics of the water column differed during the course of the drift period. Care should therefore be taken interpreting the results from the water column and vertical flux, as the sediment traps may have drifted through areas with patchy distribution of both phytoplankton and zooplankton. Except for those at Stn I, 1 to 3 of the upper traps were situated in the euphotic zone. This might have lead to some overestimation of vertical flux due to production inside the traps, but due to low production below $20 \mathrm{~m}$ (Vernet et al. 1998) we have reason to believe that overestimation due to production was insignificant.

Field results have shown that phytoplankton and phytodetritus may aggregate and sink rapidly out of the euphotic zone when living conditions deteriorate (Smetacek et al. 1978, Smetacek 1980, Wassmann et al. 1990). There is, however, no strict relationship between nutrient depletion and enhanced sinking rates (Bienfang et al. 1982, 1983) or nutrient depletion and aggregation potential on a species level (e.g. Kiørboe \& Hansen 1993). Extensive sedimentation of phytoplankton might also take place during earlier stages of blooms due to aggregation (Kiørboe 1993, Kiørboe et al. 1994) or deterioration of living conditions (i.e. light limitation; Waite \& Thompson 1992)

High POC and chl a vertical flux and chla/phaeo ratios $>1$ at the 3 northernmost stations (I, II, III) indicate sinking of phytoplankton or phytodetritus in the upper water column, while at Stn IV the vertical flux of both POC and chl a was low, indicating sinking of less phytoplankton and more decomposed material. Environmental and biological factors that might have been important for the vertical flux of phytoplankton at the 4 stations in the Barents Sea in May 1993 will be evaluated in the following discussion. The importance of loss of phytoplankton due to sinking compared to loss due to grazing will also be discussed.

\section{Bloom development, nutrient and light conditions and vertical flux of microplankton}

Reduced nutrient concentrations and high concentrations of chl $a$ and diatoms at Stn I indicated a welldeveloped ice edge bloom. The species composition with Fragilariopsis sp. and Thalassiosira spp. and Chaetoceros spp. is typical of marginal ice zones (Horner 1989, Kang \& Fryxell 1992) and later stages of arctic spring blooms (Quillfeldt 1996). Diatoms are less likely to dominate at $\mathrm{Si}(\mathrm{OH})_{4}$ concentrations $<2 \mu \mathrm{M}$ (Doering et al. 1989, Egge 1993) and may aggregate, sink and leave the euphotic zone before phosphate and nitrate become depleted (Wassmann et al. 1997). Considering nutrient conditions and species composition, high loss of phytoplankton through sinking could be expected at Stn I. The high vertical flux of POC and chl $a$ in the upper water column seems to support this assumption.

The euphotic zone (down to $0.1 \%$ light depth) at Stn I only extended to $25 \mathrm{~m}$ depth (Vernet et al. 1997), and the daily loss rate of chl a at $30 \mathrm{~m}(3.5 \%$ of standing stock $\mathrm{d}^{-1}$ ) indicates increased sinking out of the euphotic zone. The uniform distribution of nutrients and biomass in the upper $50 \mathrm{~m}$ though indicates mixing of the water above the pycnocline. The total upper water column down to the pycnocline must therefore be considered periodically part of the euphotic zone. The vertical flux rates at Stn I were reduced below the pycnocline and chl a loss rate at $60 \mathrm{~m}$ was only $0.4 \%$ of standing stock $\mathrm{d}^{-1}$. Although there was a considerable amount of phytoplankton sinking in the euphotic zone, little material escaped from the mixed layer, either due to mixing or due to other forms of loss (i.e. grazing). The low daily loss rates through sinking imply that no extensive sedimentation of phytoplankton took place, despite high vertical chl a flux at Stn I. This conclusion finds support in that Stn I did not have significantly different daily loss rates of phytoplankton and chl a com- 
pared to Stn IV, and both Stns II and III had higher daily loss rates. Stns II, III and IV all experienced high nutrient concentrations.

The phytoplankton community at both Stns II and III was dominated by species (Phaeocystis sp. colonies, Chaetoceros spp. and Thalassiosira spp.), often observed during spring bloom in the Barents Sea (Rey et al. 1987, Sakshaug \& Skjoldal 1989, Druzhkov \& Makarevich 1992). Despite differences in vertical stability and water column characteristics, Stns II and III had similarities with regard to phytoplankton composition, suspended biomass and vertical flux. Insignificant differences in biomass and species composition above and below the pycnocline, however, indicate that the upper layer of melt water at Stn II had recently formed or arrived at this site and had not yet influenced the general biomass and species composition. Low biomass and reduced, but still high, nutrient concentrations indicate that the blooms at Stns II and III were in an early phase of bloom development, when high loss rates should not be expected. A comparison of chl a daily loss rates from Stns II and III and previous observations made in the same area during conditions of nutrient depletion (Wassmann et al. 1990) show that the loss rates were 3 to 4 times higher in 1993. This indicates that loss of phytoplankton at Stns II and III through sinking was extensive during the period of investigation.

Reduced light due to increased ice cover or mixing of the water column are factors that may induce less favourable growth conditions and thus induce sinking of phytoplankton. The ice cover at Stn II was less than that at Stn I and it decreased during the drift. Therefore light limitation by increased ice-cover is not a satisfactory explanation for the increased loss of phytoplankton at Stn II. High primary production (Vernet et al. 1998) and reduction in nutrient concentrations during drift confirm this conclusion.

Stn III was lacking a strong stratification and unstratified water is sensitive to mixing by wind (Sakshaug et al. 1994), which may induce light limitation. Observations of spring bloom development in weakly stratified waters are not rare (Eilertsen 1993, Townsend et al. 1993. Wassmann et al. 1996) and have frequently been made in the Atlantic sector of the Barents Sea (e.g Skjoldal \& Rey 1989, Wassmann et al. 1998). Wind conditions were calm both before and during drift and CTD and fluorescence profiles (data not shown) taken during the drift did not indicate enhanced mixing This conclusion is further supported by the results from Stn IV. Temperature, salinity, stability and biomass (in terms of chl a) were similar at Stns IV and III, but Stn IV had low vertical flux of organic matter and low daily loss rates. Hydrographical conditions seem therefore not to give any satisfactory explanation for the increased loss of phytoplankton at Stns II and III.

\section{Species-specific sinking}

Different species or groups of species dominated the phytoplankton biomass at the 4 stations, but generally the same species were found at all stations. Speciesspecific differences in sinking behaviour have been found in other ecosystems (e.g. Passow 1991) as well as in the Barents Sea (P. Wassmann \& F. Rey unpubl.). Species-specific loss rates were therefore calculated to see if the species composition and species-specific loss rates could explain the differences in loss rates between the stations.

A comparison of the composition of suspended phytoplankton in the mixed layer and sinking cells at $60 \mathrm{~m}$ (Fig. 8, Table 2) revealed no major differences between groups at each station. There were increased daily loss rates of ciliates at Stn II and dinoflagellates at Stn III, but this conclusion may not be significant due to the low cell numbers in the samples. The same may be valid for Phaeocystis sp. and Thalassiosira spp. at Stn IV. The dominance of certain groups of phytoplankton in the sinking material at $60 \mathrm{~m}$ was thus not due to higher sinking rates of specific species. The high loss rates of phytoplankton at Stns II and III included the entire phytoplankton community.

\section{Extracellular carbon and aggregation - a probable explanation for increased loss rates?}

The production of extracellular carbon (high-molecular-weight carbohydrates) by phytoplankton may influence the fate of the particulate primary production. Mucilage and particulate matter which is sticky le.g. transparent exopolymer particles (TEP); Alldredge et al. 1993, Riebesell et al. 1995] may increase coagulation (Jackson 1990) and thus increase the vertical flux of particles. During the investigation in 1993, Vernet et al. (1998) found an increasing proportion of primary production as extracellular carbon (39 to $55 \%$ of primary production) from Stn I to Stn III. Stn IV, however, had the lowest production of extracellular carbon with only $18 \%$ of primary production. Extraceliular carbon includes both mucilage and dissolved organic carbon (DOC) and probably consist of polysaccharides (Vernet et al. 1998). Although production of extracellular carbon was also high at Stn I, production of extracellular carbon compared to standing stock of phytoplankton was highest at Stns II and III. Based on the species composition, diatoms are believed to have dominated the production of extracellular carbon at Stn I, while both Phaeocystis sp. and diatoms contributed to the production of extracellular carbon at Stns II and III (Vernet et al. 1998). Production of extracellular carbon may have increased the aggregation potential of sus- 
pended particles and consequently have caused the high daily loss rates at Stns II and III. Direct observations of the aggregation potential of the natural community were unfortunately not carried out. Therefore, we only have circumstantial evidence that aggregation was the main reason for the observed differences in vertical export of phytoplankton among the 4 stations.

\section{Dissolution of sinking Phaeocystis sp. colonies below $60 \mathrm{~m}$}

Sedimentation of Phaeocystis sp. colonies has been observed in the Barents Sea and in northern Norwegian fjords, but vertical flux has been shown to decrease below 40 to $60 \mathrm{~m}$ depths (Wassmann et al. 1990, Riebesell et al. 1995). A dissolution of Phaeocystis sp. colonies in the upper aphotic zone and at midwater depth has been suggested (Passow \& Wassmann 1994, Wassmann 1994)

In the Barents Sea in 1993 vertical flux of diatoms showed minor variations or a small decrease with depth, while the vertical flux of Phaeocystis sp. in terms of carbon showed a sharp decline below $60 \mathrm{~m}$ at all stations. These observations are consistent with earlier observations, but the matrix from Phaeocystis sp. colonies was found in the traps at 100 and $200 \mathrm{~m}$ in comparable numbers to the vertical flux of colonies at $60 \mathrm{~m}$. We may therefore conclude that the matrix of Phaeocystis sp. may reach the deep water of the Barents Sea, but that the cells may escape from the matrix during sinking. Geographical differences in sinking and dissolution of Phaeocystis sp. cannot be excluded, but use of preservatives that do not preserve colonial matrix may be a reason for lacking observations of sinking Phaeocystis sp. matrix in other areas. In terms of vertical flux of carbon, the matrix of Phaeocystis sp. colonies may be less important, but if they act as scavengers for other particles, creating aggregates with high sinking speed, the matrix may be of significance for vertical carbon export.

\section{Meso- and macrozooplankton influence on vertical flux}

The vertical flux of both chl $a$ and POC decreased with depth in the upper water column at all stations and only a small fraction of intact phytoplankton reached deeper waters. PPC at the 4 stations comprised 5 to $9 \%$ of the vertical POC flux at 100 and $200 \mathrm{~m}$ (data not shown), indicating that identifiable phytoplankton cells represented a small portion of the vertical flux at these depths. The decrease in vertical POC and chl a flux was accompanied by a change in pigment composition to a dominance by phaeo at depth, indicating that sinking matter in the deeper water column consisted of degraded matter. This indicates that the sinking material was dominated by faecal material, which was confirmed by data from $J$ Urban-Rich (unpubl. data on total faecal pellets carbon). The vertical flux data thus indicate both retention of phytoplankton biomass due to grazing and a considerable contribution of faecal matter to vertical flux.

Calanoid copepods are regarded as the main herbivorous species during spring in the Barents Sea (Bâmstedt et al. 1991, Tande 1991), but experiments carried out by Hansen et al. (1996) during the cruise in 1993 indicated low copepod grazing rates $(0.2$ to $1 \%$ of daily primary production, or 1.5 to $15 \mathrm{mg} \mathrm{C} \mathrm{m} \mathrm{m}^{-2} \mathrm{~d}^{-1}$ ) in the euphotic zone due to low biomass of the most important herbivorous copepods. Faecal pellet production by calanoid copepods was also too small to contribute significantly to vertical flux (Urban-Rich 1997). Mesozooplankton grazing activity can thus explain neither the observed retention of phytoplankton nor the vertical flux of faecal matter.

This points to a possible underestimation of zooplankton grazing. Mesozooplankton grazing potential was estimated only for the most dominant copepod species, and macrozooplankton species such as euphausiids, pteropods, and amphipods from the water column and under-ice fauna were not evaluated (Hansen et al. 1996). However, euphausiids, for example, are important contributors to zooplankton biomass in the Barents Sea (Dalpadado \& Skjoldal 1991). Krill and other macrozooplankton species may thus have been important consumers of phytoplankton and contributors to the vertical flux of matter, as shown in other geographical areas (von Bodungen et al. 1987, Bathmann et al. 1991, Riebesell et al. 1995). Therefore copepod grazing per se might not have been underestimated, but the total grazing pressure from large zooplankton might have been underestimated due to incomplete sampling. This is further confirmed by the observation of krill pellets in the sedimented material. (J. Urban-Rich pers. comm.).

\section{Microzooplankton influence on vertical flux}

Protozoan grazing was shown to be much higher than that of copepods during this study (Hansen et al. 1996: Table 3: 125 to $720 \mathrm{mg} \mathrm{C} \mathrm{m} \mathrm{m}^{-2}$ ). Microzooplankton distribution followed, in general, that of phytoplankton and was dominated by heterotrophic dinoflagellates (Hansen et al. 1996). Heterotrophic dinoflagellates are known to be able to prey on phytoplankton similar to their own size, particularly the large forms that feed using feeding appendages (Jacobson \& Anderson 1986). Due to high grazing rates 
Table 3. Grazing rates of meso- and microzooplankton integrated from 0 to $50 \mathrm{~m}$ (from Hansen et al. 1996)

\begin{tabular}{|c|c|c|}
\hline Stn & $\begin{array}{l}\text { Grazing potential of } \\
\text { mesozooplankton } \\
\left(\mathrm{mg} \mathrm{C}^{-2} \mathrm{~d}^{-1}\right)\end{array}$ & $\begin{array}{l}\text { Grazing potential of } \\
\text { microzooplankton } \\
\text { (mg C m } \mathrm{C}^{-1} \text { ) }\end{array}$ \\
\hline I & 5 & 720 \\
\hline III & 2.0 & 280 \\
\hline III & 1.5 & 125 \\
\hline IV & 15 & 425 \\
\hline
\end{tabular}

and absence o: faecal pellet formation, or production of small and slow-sinking pellets, microzooplankton may contribute to the retention of biomass and nutrients in the euphotic zone (Antia 1991). Although pellets from microzooplankton may be important components of the vertical flux (Nöthig \& von Bodungen 1989), microzooplankton acting as the main consumers of phytoplankton may reduce the export of carbon or phaeo compared to scenarios where mesozooplankton are the main herbivores (Buck \& Newton 1995).

Protozoan grazing was largest at Stns I and IV (Hansen et al 1996). Both stations had high phytoplankton biomass and high primary production (Vernet et al. 1998; , but low daily loss rates. The reduction in vertical chl $a$ flux and change of pigment composition mainly took place above $60 \mathrm{~m}$ at Stns I and IV, where microzooplankton also dominated. The low daily loss rates of biogenic matter to deeper waters at these stations may therefore partly be explained by retention due to microzooplankton grazing. The distribution of microzooplankton and the large grazing potential gave the microzooplankton the possibility not only of further controlling phytoplankton production, but also of retaining biogenic matter and nutrients in the upper water column at these stations.

Stns II and III experienced lower protozoan grazing pressure between 0 and $50 \mathrm{~m}$ compared to Stns I and IV (Hansen et al. 1996). This coincided with larger vertical flux of phytoplankton to deeper water. It is uncertain to what extent protozoans are able to graze on Phaeocystis sp. colonies, but ciliates and heterotrophic dinoflagellates are probably capable of grazing on single cells liberated from colonies (Lancelot et al. 1991).

\section{CONCLUSION}

The interpretation of the present material is complicated by the limited investigation time and the complexity of the pelagic community along the gradient. Careful analysis of the results, however, indicates that hydrography, nutrient status and light did not have a profound influence on the vertical flux of phytoplank- ton during this investigation. The results show that high vertical flux is not necessarily connected to high daily loss rates, but may be due to low or moderate daily loss rates of a large suspended biomass. It may be relevant to question the use of the term mass sedimentation as used by e.g. Wassmann et al. (1990). High vertical flux of phytoplankton (or other particles), especially during conditions with low nutrient concentrations, is often referred to as mass sedimentation. The use of this term under such conditions may be misleading, and should be reserved for scenarios of high daily loss rates

High daily loss rates of phytoplankton from the euphotic zone was observed at the 2 stations (II and III) with high nutrient concentrations. The high loss rates were possibly due to production of extracellular carbon, which may have increased the aggregation potential of the phytoplankton community. This indicates that phytoplankton in the Barents Sea during spring may be subjected to aggregation and sinking before the termination of the spring bloom by nutrient or light limitation.

Evidence of incomplete dissolution of Phaeocystis sp. colonies was observed to a depth of $200 \mathrm{~m}$. The results show that the matrix of Phaeocystis sp. may reach the deep water of the Barents Sea, but that the cells probably escape the matrix during sinking. The importance of sinking Phaeocystis sp. for the carbon flux in the Barents Sea is, however, still uncertain.

Only a small fraction of intact phytoplankton reached deeper waters due to retention by grazers, and the vertical flux of biogenic matter to deeper water masses was dominated by faecal matter. Earlier hypotheses (Eilertsen et al. 1989, Wassmann et al. 1990, Wassmann \& Slagstad 1993) based on the assumption that mesozooplankton grazers (i.e. calanoid copepods) are important regulators of the vertical flux during spring in the Barents Sea were shown to be inadequate in explaining the retention of phytoplankton matter in the upper water column. Mesozooplankton probably did not play an important role in retaining matter in the upper water column. Protozoan grazing was more important in terms of retaining organic matter and nutrients in the upper water. There are indications that macrozooplankton (i.e. euphausiids), as mediator of vertical flux through production of fast-sinking pellets, were important in structuring the carbon flow in the pelagic system.

These conclusions imply that not only the physical environment but also biological processes are important factors in the regulation of the vertical flux of biogenic matter in the northern and central Barents Sea during the spring period. In future studies phytoplankton-related processes such as production of extracellular carbon and aggregation should be studied, and the 
entire size spectra of phytoplankton consumers and their role in structuring the carbon flow in the pelagic system should be considered.

Acknowledgements. The assistance of the crew of RV 'Jan Mayen' is gratefully acknowledged. We thank Maria Vernet for analysis of the chl a samples and Juanita Urban-Rich for access to faecal pellets data. Frøydis Strand prepared the final figures. The investigation was supported by the Norwegian Research Council and is a contribution from the Norwegian Research Programme of North Norweglan Coastal Ecology (MARE NOR).

\section{LITERATURE CITED}

Alldredge AL, Passow U, Logan BE (1993) The abundance and significance of a class of large, transparent organic particles in the ocean. Deep-Sea Res 40:1131-1140

Andreassen 1, Nöthig EM, Wassmann P (1996) Vertical particle flux on the shelf off northern Spitsbergen, Norway. Mar Ecol Prog Ser 137:215-228

Antia AN (1991) Microzooplankton in the pelagic food web of the East Greenland Sea and its role in sedimentation processes. Ber Sonderforsch 313 Univ Kiel 33:1-110

Båmstedt U, Eilertsen HC, Tande KS, Slagstad D, Skjoldal HR (1991) Copepod grazing and its potential impact on the phytoplankton development in the Barents Sea. In: Sakshaug E, Hopkins C, Øritsland N (eds) Proceedings from the Pro Mare Symposium on Polar Marine Ecology. Polar Res 10:339-354

Bathmann U, Fischer G, Müller PJ, Gerdes D (1991) Shortterm variations in particulate matter sedimentation of Kapp Norvegia, Weddell sea, Antartica: relation to water mass advection, ice cover, plankton biomass and feeding activity. Polar Biol 11:185-195

Bienfang PK, Harrison PJ, Quarmby LM (1982) Sinking rate response to depletion of nitrate, phosphate and silicate in four marine diatoms. Mar Biol 67:295-302

Bienfang PK, Szyper J, Laws E (1983) Sinking rate and pigment responses to light-limitation of a marine diatom: implications to dynamics of chlorophyll maximum layers. Oceanol Acta 6:55-62

Bloesch J (1997) Towards a new regeneration of sediment traps and a better measurement/understanding of settling particle flux in lakes and oceans: a hydrodynamical protocol. Aquat Sci 58:283-296

Buck KR, Newton J (1995) Fecal pellets flux in Dabob Bay during a diatom bloom: contribution of microzooplankton. Limnol Oceanogr 40:306-315

Dalpadado P. Skjoldal HR (1991) Distribution and life history of krill from the Barents Sea. In: Sakshaug E, Hopkins $\mathrm{C}, \varnothing$ ritsland $\mathrm{N}$ (eds) Proceedings from the Pro Mare Symposium on Polar Marine Ecology. Polar Res 10: $443-460$

Doering PH, Oviatt CA. Beatty LL, Banzon VF, Rice R, Kelly SP, Sullivan BK, Frithsen JB (1989) Structure and function. in a model coastal ecosystem; silicon, the benthos and eutrophication. Mar Ecol Prog Ser 52:287-299

Druzhkov N, Makarevich P (1992) Structural characteristic of the micro-phytoplankton seasonal development in the coastal ecosystem. In: Phytoplankton of the Barents Sea. KNC RAN Publ, Apatity, p 83-96

Egge JK (1993) Nutrient control of phytoplankton growth: effects of macronutrient composition (N, P, Si) on species succession. Dr Scient thesis, Dept of Fisheries and Marine Biology, University of Bergen

Eilertsen HC (1993) Spring blooms and stratification. Nature $363: 24$

Eilertsen HC, Tande KS, Hegseth EN (1989) Potential of herbivorous copepods for regulating the spring phytoplankton bloom in the Barents Sea. Rapp Pv Réun Cons Int Explor Mer 188:154-163

GOFS (1989) Sediment trap technology and sampling. Report of the U.S. GOFS working group of sedimenting trap technology and sampling

Hansen B, Christiansen S, Pedersen G (1996) Plankton dynamics in the Marginal Ice Zone of the central Barents Sea during spring: carbon flow and structure of the grazer food chain. Polar Biol 16:115-128

Holm-Hansen O, Lorenzen CJ, Holmes RW, Strictland JDH (1965) Fluorometric determination of chlorophyll. J Cons Perm Int Explor Mer 30:3-15

Horner RA (1989) Arctic sea-ice biota. In: Herman Y (eds) The Arctic seas. Van Nostrand Reinhold Company, New York, p $123-146$

Jackson GA (1990) A model of the formation of marine algal flocs by physical coagulation processes. Deep-Sea Res 37:1197-1211

Jacobson DM, Anderson JM (1986) Thecate heterotrophic dinoflagellates: feeding behaviour and mechanisms. J Phycol 22:249-258

Kang SH, Fryxell GA (1992) Fragilariopsis cylindrus (Grunow) Krieger: the most abundant diatom in water column assemblages of Antarctic marginal ice-edge zones. Polar Biol 12:609-627

Kiørboe T (1993) Turbulence, phytoplankton cell size, and the structure of pelagic food webs. Adv Mar Biol 29:2-72

Kiorboe T, Hansen JLS (1993) Phytoplankton aggregate formation: observations of patterns and mechanisms of cell sticking and the significance of exopolymeric material. J Plankton Res 15:993-1018

Kiørboe T, Lundsgaard C, Olesen M, Hansen JL (1994) Aggregation and sedimentation processes during a spring bloom: a field experiment to test coagulation theory. J Mar Res 52:297-323

Lancelot C, Billen G, Barth H (1991) The dynamics of Phaeocystis blooms in nutrient enriched coastal zones. Water Pollut Res Rep 23

Legendre L (1990) The significance of microalgal blooms for fisheries and for the export of particulate organic carbon in oceans. J Plankton Res 12:681-699

Loeng $\mathrm{H}$ (1991) Features of the physical oceanographic conditions on the Barents Sea. In: Sakshaug E, Hopkins C, Oritsland $N$ (eds) Proceedings from the Pro Mare Symposium on Polar Marine Ecology. Polar Res 10: 5-18

Nothig EM, von Bodungen B (1989) Occurrence and vertical flux of faecal pellets of probably protozoan origin in the southeastern Weddell Sea (Antarctica). Mar Ecol Prog Ser $56: 281-289$

Passow U (1991) Species-specific sedimentation and sinking velocities of diatoms. Mar Biol 108:449-455

Passow U, Wassmann P (1994) On the trophic fate of Phaeocystis pouchetii (Hariot): IV. The formation of marine snow by P. pouchetii. Mar Ecol Prog Ser 104:153-161

Pedersen G, Tande K, Nilssen E (1995) Temporal and regional variation in the copepod community in the central Barents Sea during spring and early summer 1988 and 1989. J Plankton Res 17:268-282

Quillfeldt $\mathrm{CH}$ von (1996) Ice algae and phytoplankton in North Norwegian and Arctic waters: species composition, succession and distribution. PhD thesis, Univ of Tromsø 
Rey $F$, Loeng $H$ (1985) The influence of ice and hydrographic conditions on the development of stress on marine organisms. In: Gray J, Christiansen M (eds) Marine biology of polar regions and effect of stress on marine organisms. Wiley, Chichester, p 49-63

Rey F, Skjoldal H, Slagstad D (1987) Primary production in relation to climatic change in the Barents Sea. In: Loeng $H$ (ed) Proc 3rd Soviet-Norwegian Symp. The effect of oceanographic conditions on distribution and population dynamics of commercial fish stocks in the Barents Sea. Institute of Marine Research, Bergen

Riebesell U, Reigstad M, Wassmann P, Noji T, Passow U (1995) On the trophic fate of Phaeocystis pouchetii (Hariot): VI. Significance of Phaeocystis-derived mucus for vertical flux. Neth J Sea Res 33:193-203

Rousseau V, Mathot S, Lancelot C (1990) Calculating carbon biomass of Phaeocystis sp. from microscopic observations. Mar Biol 107:305-314

Sakshaug E, Bjorge A, Gulliksen B, Loeng $H$, Mehlum $F$ (1994) Structure, biomass distribution, and energetics of the pelagic ecosystem in the Barents Sea: a synopsis. Polar Biol 1.4:405-411

Sakshaug E, Hopkins C, Øritsland N (1991) Proceedings of the Pro Mare Symposium on Polar Marine Ecology. Polar Res 10:1-61C

Sakshaug E, Skjoldal HR (1989) Life at the ice edge. Ambio 1.8:60-67

Skjoldal HR, Hassel A, Rey F, Loeng H (1987) Spring phytoplankton development and zooplankton reproduction in the central Barents Sea in the period 1979-1984. In: Loeng $\mathrm{H}$ (ed) Proc 3rd Soviet-Norwegian Symp. The effect of oceanographic conditions on distribution and population dynamics of commercial fish stocks in the Barents Sea. Institute of Marine Research, Bergen, p 59-89

Skjoldal HR, Rey F (1989) Pelagic production and variability of the Barents Sea ecosystem. In: Sherman K, Alexander L. (eds) Biomass and geography of large marine ecosystems. Westview Press, Boulder, CO, p 243-283

Smetacek V (1980) Annual cycle of sedimentation in relation to plankton ecology in the western Kiel Bight. Estuar Coast Mar Sci 11:477-490

Smetacek $V$, von Bodungen $B$, Knoppers $B$, Peinert $R$, Pollehne F. Stegmann P, Zeitzschel B (1984) Seasonal stages characterising the annual cycle of an inshore pelagic system. Rapp Pv Réun Cons Int Explor Mer 183: $126-135$

Smetacek V, von Bröckel K, Zeitzschel B, Zenk W (1978) Sedimentation of particulate matter during a phytoplankton spring bloom in relation to the hydrographical regime. Mar Biol 47:211-226

Staresınic N, Rowe GT, Shaughnessey D, Williams AJ (1978) Measurements of the vertical flux of particulate organic matter with a free-drifting sediment trap. Limnol Oceanogr 23:559-563

Strathmann (1967) Estimating the organic carbon content of phytoplankton from cell volume or plasma volume. Limnol Oceanogr 12:411-418

Editorial responsibility: Otto Kinne (Editor), Oldendorf/Luhe, Germany
Tande K (1991) Calanus in North Norwegian fjords and in the Barents Sea. In: Sakshaug E. Hopkins C, Øritsland N (eds) Proceedings from the Pro Mare Symposium on Polar Marine Ecology. Polar Res 10:389-408

Townsend DW, Keller MD, Sieracki ME, Ackleson S (1993) Spring phytoplankton blooms in the absence of vertical water column stratification. Nature 360:59-62

Urban-Rich J (1997) Copepod fecal pellet contributions to organic carbon and amino acid flux. PhD thesis, University of Maryland, College Park, MD

Vernet $M_{1}$ Matrai PA, Andreassen I (1998) Synthesis of particulate and extracellular carbon by phytoplankton at the marginal ice zone in the Barents Sea. J Geophys Res 103(G1):1023-1037

von Bodungen B, Fisher G, Nöthig EM, Werfer G (1987) Sedimentation of krill faeces during spring development in Bransfield Strait, Antarctica. In: Degens E, Izdar E, Honjo $S$ (eds) Particle flux in the ocean. Mitt Geol-Paläontol Inst Univ Hamburg, p 243-257

Waite AM, Thompson PA (1.992) Does energy control the sinking rates of marine diatoms? Limnol Oceanogr 37: $468-477$

Wassmann P (1989) Sedimentation of organic matter and silicate from the euphotic zone of the Barents Sea. Rapp Pv Réun Cons Int Explor Mer 188:108-114

Wassmann P (1991a) Dynamics of primary production and sedimentation in shallow fjords and polls of Western Norway. Oceanogr Mar Biol Annu Rev 29:87-154

Wassmann P (1991b) Sampling and analysis of marine particles with PEBENOCO (Pelagic-Benthic Coupling in the Norwegian Coastal Zone), University of Tromsø, Norway. In: Hurd D, Spencer D (eds) Marine particles: analysis and characterization. American Geophysical Union, Washington, DC, p $97-99$

Wassmann P (1994) Significance of sedimentation for the termination of Phaeocystis blooms. J Mar Syst 5:81-1.00

Wassmann P, Vernet M, Mitchell BG, Rey F (1990) Mass sedimentation of Phaeocystis pouchetii in the Barents Sea. Mar Ecol Prog Ser 66:183-195

Wassmann P, Slagstad D (1993) Seasonal and annual dynamics of carbon flux in the Barents Sea: a model approach. Polar Biol 13:363-372

Wassmann P, Martinez R, Vernet M (1994) Respiration and biochemical composition of sedimenting organic matter during summer in the Barents Sea. Cont Shelf Res 14: 79-90

Wassmann P, Andreassen I, Reigstad M, Slagstad D (1996) Pelagic-benthic coupling in the northeastern North Atlantic: the role of episodic events. PSZN I: Mar Ecol $17: 447-471$

Wassmann P. Egge J, Reigstad M, Aksnes D (1997) Influence of silicate on vertical flux of particulate biogenic matter. Mar Pollut Bull (in press)

Wassmann $P$, Ratkova $T$, Andreassen $I$, Vernet $M$, Pedersen G. Rey F (1998) Spring bloom development in the marginal ice zone and the central Barents Sea. PSZN I: Mar Ecol (in press)

Submitted: September 16, 1997; Accepted: January 2, 1998 Proofs received from author(s): July 30, 1998 